PUBLISHER CORRECTION

\title{
Publisher Correction: Comprehensive genomic characterization of gene therapy-induced T-cell acute lymphoblastic leukemia
}

Peter Horak (iD, Sebastian Uhrig, Maximilian Witzel, Irene Gil-Farina, Barbara Hutter (iD, Tim Rath, Laura Gieldon, Gnana Prakash Balasubramanian, Xavier Pastor, Christoph E. Heilig, Daniela Richter, Evelin Schröck, Claudia R. Ball, Benedikt Brors iD, Christian J. Braun (D), Michael H. Albert, Claudia Scholl, Christof von Kalle, Manfred Schmidt, Stefan Fröhling, Christoph Klein (iD and Hanno Glimm

(c) The Author(s) 2021

Leukemia (2021) 35:3633; https://doi.org/10.1038/s41375-021-01364-5

Correction to: Leukemia https://doi.org/10.1038/s41375-020-0779-z, published online 03 March 2020

The article Comprehensive genomic characterization of gene therapy-induced T-cell acute lymphoblastic leukemia, written by Peter Horak, Sebastian Uhrig, Maximilian Witzel, Irene Gil-Farina, Barbara Hutter, Tim Rath, Laura Gieldon, Gnana Prakash Balasubramanian, Xavier Pastor, Christoph E. Heilig, Daniela Richter, Evelin Schröck, Claudia R. Ball, Benedikt Brors, Christian J. Braun, Michael H. Albert, Claudia Scholl, Christof von Kalle, Manfred Schmidt, Stefan Fröhling, Christoph Klein \& Hanno Glimm, was originally published Online First without Open Access. After publication in volume 34 , pages $2785-2789$, the author decided to opt for Open Choice and to make the article an Open Access publication. Therefore, the copyright of the article has been changed to (c) The Author(s) [year of online publication] and the article is forthwith distributed under the terms of the Creative Commons Attribution.

\section{FUNDING}

Open Access funding enabled and organized by Projekt DEAL.

\begin{abstract}
Open Access This article is licensed under a Creative Commons Attribution 4.0 International License, which permits use, sharing, adaptation, distribution and reproduction in any medium or format, as long as you give appropriate credit to the original author(s) and the source, provide a link to the Creative Commons license, and indicate if changes were made. The images or other third party material in this article are included in the article's Creative Commons license, unless indicated otherwise in a credit line to the material. If material is not included in the article's Creative Commons license and your intended use is not permitted by statutory regulation or exceeds the permitted use, you will need to obtain permission directly from the copyright holder. To view a copy of this license, visit http://creativecommons. org/licenses/by/4.0/.
\end{abstract}

(c) The Author(s) 2021 